\title{
The climate and environment of a Pliocene warm world
}

Ulrich Salzmann $^{\mathrm{a}^{*}}$, Mark Williams ${ }^{\text {b.c }}$, Alan M. Haywood ${ }^{\mathrm{d}}$, Andrew L. A. Johnson ${ }^{\mathrm{e}}$, Sev Kender $^{c}$ \& Jan Zalasiewicz ${ }^{b}$

a - School of the Built and Natural Environment, Northumbria University, Ellison Building, Newcastle upon Tyne NE1 8ST, UK, ulrich.salzmann@northumbria.ac.uk

b - Department of Geology, University of Leicester, University Road, Leicester LE1 7RH, UK, mri@le.ac.uk (M. Williams) and jaz1@le.ac.uk (J. Zalasiewicz)

c - British Geological Survey, Keyworth, Nottingham, NG12 5GG, UK, sev.kender@bgs.ac.uk

d-School of Earth and Environment, University of Leeds, Leeds, LS2 9JT, UK, a.haywood@see.leeds.ac.uk

e - Geographical, Earth and Environmental Sciences, School of Science, University of Derby, Derby DE22 1GB, UK, A.L.A.Johnson@derby.ac.uk

"corresponding author:

E-mail address: ulrich.salzmann@northumbria.ac.uk

Tel. $+44(0) 1912273874$ 


\section{Abstract}

The Pliocene Epoch, 5.33 - 2.58 million years ago (Ma), was a generally warmer and wetter interval with atmospheric $\mathrm{CO}_{2}$-concentrations at or slightly above modern levels. This paper provides an overview of Pliocene vegetation, sea surface temperatures and climate modelling outcomes.. Most prominent changes in Pliocene biome distribution compared to today include a northwards shift of temperate and boreal vegetation zones in response to a warmer and wetter climate as well as an expansion of tropical savannas and forests at the expense of deserts. Modelling experiments using the Hadley Centre climate model identified significantly higher Pliocene sea surface temperatures at the high-latitudes with only minor warming predicted in the tropics. Global mean annual surface temperatures (MAT) are estimated to have been 2 to $3^{\circ} \mathrm{C}$ higher during the Piacenzian (3.6-2.58 Ma) than today with a reduced equator to pole gradient. The marine realm during the Pliocene was characterised by a reconfiguration of ocean gateways, particularly the narrowing of the Indonesian Seaway and closure of the Central American Isthmus, which produced essentially a modern pattern of ocean circulation. In the Southern Ocean a warm early Pliocene gave way to late Piacenzian cooling. Proxy data indicate a reduced east to west sea surface temperature gradient in the tropical Pacific during the Pliocene warmth. The Pliocene is one of the most intensively studied geological intervals of the pre-Quaternary. No other warm period in the geological past yields such a unique combination of near modern atmospheric $\mathrm{CO}_{2}$ concentrations, palaeogeography and palaeobiology. However, this paper also identifies data gaps and shortcomings in the reconstruction of Pliocene environments using proxy data and climate models on which future research should focus.

Keywords: Pliocene; vegetation; Piacenzian; GCM; climate model; sea surface temperatures

\section{Introduction}


The Pliocene Epochspans a time when the Earth experienced a transition from relatively warm conditions to a cooling climate that heralded the high magnitude glacial-interglacial oscillations of the Pleistocene Epoch. According to the latest revision of the geological time scale by the International Committee of Stratigraphy (Gibbard et al., 2010), the Pliocene now includes the Zanclean (5.33-3.6 Ma) and Piacenzian (3.6-2.58 Ma). Global mean annual surface temperatures (MAT) during the Piacenzian are estimated to have been 2 to $3^{\circ} \mathrm{C}$ higher than today (Haywood et al., 2000a, Lunt et al., 2010). The warming was particularly accentuated at high latitudes of the northern hemisphere (e.g. Ballantyne et al., 2010; Robinson, 2009) resulting in a decreased pole to equator gradient of sea and land surface temperatures (Dowsett et al., 2010). The southern high latitude warming was probably less accentuated than in the North and the reconstruction of its magnitude is still subject of controversy (e.g. Barron, 1996; Hillenbrand and Fütterer, 2002; Stroeven et al., 1996; Wilson et al., 2002). The Pliocene world was not only warmer but on most continents also wetter than today, leading to an expansion of tropical savannas and forests in Australia and Africa at the expense of deserts (e.g. Leroy \& Dupont, 1994; Dodson and Macphail, 2004).

Elevated atmospheric $\mathrm{CO}_{2}$-concentrations, ranging from 330-425 ppmv during warm interglacials have been quoted as one of the main reasons for higher global temperatures during the Pliocene (e.g. Pagani et al., 2010; Seki et al., 2010). Past $\mathrm{CO}_{2}$-concentrations close to or even higher than modern values along with a near-modern palaeogeography, ocean bathymetry and palaeobiology, suggest that the warm Pliocene climates may provide plausible comparative scenarios for interpreting the path of future climate warming during the $21^{\text {st }}$ century (e.g. IPCC 2007; Salzmann et al., 2009). However, a number of constraints prevent the Pliocene interglacial world from being a true and direct analogue for future global climate change (Haywood et al., 2011). The size of polar ice sheets might have been significantly reduced during the Pliocene causing ca. $25 \mathrm{~m}$ higher sea levels than today (Dowsett et al., 2010). The reduction in high-latitude terrestrial ice sheets and associated ice-albedo feedbacks are an additional contributing mechanism to the global Pliocene 
warmth (Haywood and Valdes, 2004; Dolan et al., this issue). However, the reduced Pliocene ice volume is likely the result of a long-term equilibrium response to a higher $\mathrm{CO}_{2-}$ level. Modern anthropogenic greenhouse gas emissions provide a rather rapid transient forcing and, due to the slow response of polar ice sheets, it is unlikely that ice sheet reduction to Pliocene levels will occur in the near future. Other constraints which hamper the use of Pliocene interglacials as a true and direct analogue for current global warming include differences between modern and Pliocene orbital configurations, uncertainties in reconstructing the nature and timing of mountain uplift, and uncertainties in the timing of ocean gateway changes. The altitude of the Rocky Mountains, for example, might have been significantly lower during the early Pliocene, which probably had strong implications for global atmospheric circulation and climate variability as demonstrated in recent climate modelling experiments (e.g. Lunt et al., 2008, Hill et al., this issue).

In this introduction we will provide a compilation and overview of global Pliocene terrestrial and marine environments reconstructed from proxy data and palaeoclimate model simulations. The review focuses on the Piacenzian (3.6-2.58 Ma) for which a significant number of proxy data and modelling studies are now available allowing a relatively robust reconstruction of Pliocene climates and environments. The mid Piacenzian warm period ( 3.3 to $3.0 \mathrm{Ma})$, sometimes shortened to MPWP, has been for many years the research focus of the international Pliocene Research, Interpretation \& Synoptic Mapping initiative PRISM (Dowsett et al., 2010) and the associated Pliocene Modelling Intercomparison Project (PlioMIP), a collaborative data analysis and climate modelling effort (Haywood et al., 2010). We will finally use the overview of global Pliocene environments to identify open questions and to provide an outlook on the future of Pliocene research.

\section{Terrestrial Pliocene}


The following reconstruction of Pliocene land surface cover is largely based on a synthesis of 202 Piacenzian marine and terrestrial palaeoenvironmental records which have been merged with outputs of the mechanistically based BIOME4 model forced by climatology derived from the Hadley Centre HadAM3 GCM model simulation (Fig. 2). Further details of the methodology and coupling strategy as well as a full reference list of literature used for the biome reconstruction was given by Salzmann et al. (2008). The distribution of global biomes indicates for the interglacial and cooler "glacial" periods of the Pliocene a generally warmer and wetter climate than today.

\subsection{Tropical and sub-tropical vegetation zones}

The palaeobotanical data available for the tropical zone of Africa, Australasia and South America suggest that the evergreen rain forest belt was, during the Piacenzian, nearly in the same latitudinal position as today (Fig.2, e.g. Kershaw and Sluiter, 1982; Suc et al., 1995). North and south of the rainforest belt, the adjacent tropical woodlands, savannas and shrublands expanded during the Piacenzian and covered much larger areas than today (e.g. Leroy and Dupont, 1994; Dodson and Macphail, 2004). The higher precipitation caused a retraction of subtropical deserts and semi-desert. Most of the modern arid and semi-arid climate zones in Africa, central Australia and the Arabian Peninsula were covered during the Pliocene with temperate and tropical xerophytic shrublands and grasslands (Fig. 2). Semiarid Amaranthaceae-Chenopodiaceae shrublands and grassland also extended northwards into southern Spain and North Africa (e.g. Fauquette et al., 1999). While temperature was also augmented here, precipitation remained relatively unchanged or increased only slightly, creating in the southern Mediterranean a rare example of a drier-than-modern Pliocene climate.

Palaeobotanical information on the history of the Pliocene tropical and subtropical vegetation of South America is extremely scarce. However, evidence from vertebrate palaeontology 
and phytoliths indicates a regionally more humid and warmer climate. A mosaic of open forests, savanna and grassland biomes covered most of northern and southern Argentina (e.g. Reguero et.al., 2007). The palaeo-records provide evidence for an increasing presence of savanna-adapted mammals which arrived from North America following the Pliocene closure of the Central American Seaway.

\subsection{Temperate and warm-temperate zones}

Warm-temperate evergreen conifer forests covered the western and southernmost coastal zones of North America, indicating warmer or near modern temperatures throughout the Piacenzian (e.g. Thompson, 1991; Hansen et al., 2001). Warm-temperate broadleaved forest became the dominant vegetation in most parts of Europe and Southeast Asia throughout the Pliocene (Fig. 2). The forests consisted of a combination of tropical, subtropical and temperate floral elements which have no modern-analogue. Characteristic elements of the European Middle Pliocene assemblages include Fagus, Quercus, Ulmus, Tilia, Pinus and Betula as well as thermophilous taxa such as Engelhardia, Liquidambar, Sequoia, Taxodium, Gingko, Nyssa, Glyptostrobus and Magnolia. For the northern Mediterranean and western Europe the highly diverse forest vegetation implies MATs 3-6 ${ }^{\circ} \mathrm{C}$ higher than today with an increase in mean annual precipitation (MAP) by $400 \mathrm{~mm}$ and $230 \mathrm{~mm}$ respectively (e.g. Utescher et al., 2000; Fauquette et al., 1999). With decreasing temperatures throughout the course of the Pliocene the dominant European vegetation changed gradually from highly diverse subtropical and warm-temperate forests to temperate deciduous forests with East Asian and North American affinities (Mai, 1995).

The modern boreal conifer-dominated forest zone of central and northern Europe was covered during the Pliocene with cool-temperate mixed forests implying significantly higher mean annual winter and summer temperatures than today (Mai, 1995). Marine pollen profiles from the North Atlantic indicate that the Piacenzian temperate forests extended in northeastern America and Norway northward to $60^{\circ} \mathrm{N}$ and $70^{\circ} \mathrm{N}$, respectively (Willard, 1994). 
Carbon and oxygen isotopic variability in palaeosols suggest an expansion of $\mathrm{C}_{4}$-grasslands in central North America throughout the Miocene, which reached modern extensions in the earliest Pleistocene, by ca. 2.5 Ma (e.g. Fox and Koch, 2004). The BIOME4 model simulation predicts for west and central North America and northeast Russia a direct transition from temperate grasslands to boreal taiga forests at ca. $60^{\circ} \mathrm{N}$, which cannot be "ground-truthed" due to the lack of palaeobotanical proxy data available for these regions (Salzmann et al., 2008, Fig.2).

\subsection{Polar and sub-polar vegetation zones}

One of the most prominent differences of climate and vegetation cover between the present and the warm Pliocene world can be detected in the polar and sub-polar regions (Fig. 2). In north-east Greenland elements of taiga forest reached $82^{\circ} \mathrm{N}$ during the Piacenzian (Bennike and Boecher, 1990), whilst the Greenland ice sheet was reduced by at least 30\% (Dolan et al., this issue). Multiple palaeobotanical records allow a robust reconstruction of the Northern Hemisphere high latitudes and indicate that the polar tundra vegetation was replaced in most areas by taiga forests with dominant Picea and Pinus. The boundary between tundra and taiga was situated between $250 \mathrm{~km}$ (Siberia) and $2500 \mathrm{~km}$ (Canadian Arctic) further north than today (e.g. DeVernal and Mudie, 1989). For the Canadian high Arctic, recent multiproxy studies suggest Pliocene MATs were approximately $19^{\circ} \mathrm{C}$ warmer than at present (Ballantyne et al., 2010).

In contrast to the Arctic, Pliocene palaeobotanical data for the Antarctic continent is extremely scarce and there is great uncertainty in estimating the magnitude of temperature increase and ice sheet extent. The BIOME4 model reconstruction predicts a tundra shrub vegetation in coastal regions of Antarctica during Pliocene warm periods (Fig.2, Salzmann et al., 2008). Palaeobotanical data which could support this reconstruction comes from two sites in East Antarctica: the Sirius Group Formation (e.g. Francis and Hill, 1996) and the marine coring site DSDP Site 274 (Fleming and Barron, 1996). However, the interpretation of the 
findings at both sites is subject to controversy. Sediment reworking strongly hampers an unambiguous identification of in-situ material, which has provoked controversial debates about existing Pliocene environmental reconstructions for Antarctica and dating using age diagnostic microfossils (Stroeven et al., 1996, Wilson et al., 2002; Salzmann et al., this issue).

\section{Marine Pliocene}

During the Pliocene there was a reconfiguration of ocean gateways, particularly the narrowing of the Indonesian Seaway and closure of the Central American Isthmus, which produced essentially a modern pattern of ocean circulation (e.g. Cane and Molnar, 2001; Schmidt, 2007). Proxies for sea temperatures record marked changes in Pacific, Indian and Atlantic waters which might have resulted from these geographic changes. In the Southern Ocean a warm early Pliocene gave way to late Piacenzian cooling that is signalled by a range of sea ice proxies, and by the retreat of certain organisms to lower latitudes (e.g. Ciesielski and Weaver 1974; Berkman et al., 2004; Whitehead et al., 2005).

\subsection{Tropical Pacific}

Proxy data show a convergence of sea surface temperatures (SSTs) between the west and east Pacific when tracked backwards in time from the present to the Pliocene and this is consistent with the closure history of the Indonesian Seaway. Though evidence for the development of the West Pacific warm pool is traced back to the Miocene (Li et al., 2006), only about 3 million years ago was the through-flow of warm south Pacific waters into the Indian Ocean finally stifled (Cane \& Molnar 2001), allowing warm surface water to pool in the west Pacific and thus enhancing the marked east to west temperature gradient that is dominant at present. Foraminiferal Mg/Ca data and alkenone proxies for SSTs at three equatorial Pacific sites $(846,847,806)$, support a reduced east to west surface temperature gradient in the Early Pliocene Pacific, with the regional climate resembling a mean EI Niño 
state (Cane \& Molnar 2001; Ravelo et al. 2006). Tropical Pacific climate in the Pliocene may have been controlled by a deeper thermocline (Ravelo 2006 and references therein), which in the east resulted in warmer upwelling water. Other mechanisms may have contributed to the reduced east to west SST gradient. Federov et al. (2010) used numerical modelling to show that cyclone activity was more pronounced in the warmer Pliocene. Atmospheric circulation within these powerful cyclones could have driven warm surface ocean-waters downwards. These waters may have risen back to the surface in upwelling zones in the tropical East Pacific. Despite the oceanographic datasets that show a reduced east to west temperature gradient, there are currently few data by which to directly assess Pliocene Pacific Ocean seasonality. Organisms such as corals, bivalves and bryozoans offer a potential means to examine inter-annual temperature regimes over several years. A new annual Pliocene oxygen isotope record from coral studies has recently been published by Watanabe et al. (2011), which strongly questions the prevailing hypothesis of a permanent El Niño during Pliocene warm periods. Extensive mollusc-yielding deposits are known from Pliocene rocks in South America (e.g. Ragaini et al., 2008) but remain to be studied in detail.

\subsection{Indian Ocean and the Indonesian Seaway}

Cane \& Molnar (2001) showed that between 4 and 3 Ma the northwards drift of Papua New Guinea/Australia forced the source of seawater passing through the Indonesian Seaway to switch from a warm South Pacific to a cooler North Pacific source. Their modelling suggested that this caused reduced SSTs for the tropical eastern and central Indian Ocean of $2-3^{\circ} \mathrm{C}$, and was coupled with the reorganisation of equatorial Pacific SSTs from a more EI Niño to a more La Niña state (see above). The tectonically induced weakening of the Indonesian throughflow might have also contributed to decreasing rainfall on the Australian continent throughout the Piacenzian (Krebs et al., this issue). Foraminifer $\mathrm{Mg} / \mathrm{Ca}$ and stable isotope data from tropical East Indian Ocean DSDP site 214 were used by Karas et al. (2009) to suggest an alternative hypothesis for Indian Ocean cooling, with subsurface waters cooling by $4^{\circ} \mathrm{C}$, but no notable change in surface water temperature. Karas et al. (2009) 
attribute subsurface cooling to the same mechanism of ocean gateway change and switch to cooler North Pacific source waters, but in their scenario subsurface cooling in the East Indian Ocean forced a shoaling of the thermocline and affected the subsurface waters in the west too, through equatorial and coastal upwelling off Somalia.

\subsection{North Atlantic and Gulf Stream}

Closure of the Central American Isthmus at about 2.7 Ma (Schmidt, 2007) impacted strongly on North Atlantic oceanography by stifling the supply of buoyant and relatively fresh surface and sub-surface waters from the Pacific into the Atlantic. Less buoyant North Atlantic waters led to increased production of North Atlantic Deep Water and thus a more vigorous meridional circulation (Poore et al., 2006). In addition, a possible intensification of Mediterranean outflow at $\sim 3.3$ Ma could have brought warm salty water to the Northeast Atlantic, further intensifying NADW production (Khélifi et al., 2009). Reconstructions of North Atlantic SSTs for the early Pliocene show warmer conditions extended north of Cape Hatteras on the eastern seaboard of North America (e.g. Knowles et al., 2009; Williams et al. 2009). Warmer conditions in the Northeast Atlantic tracked by planktonic foraminifer patterns and other fossil groups suggest a response to increased meridional heat transfer from low to high latitude coupled with a greenhouse effect (Dowsett et al., 1992, 1996; De Schepper et al., this issue; Valentine et al. this issue; and Long \& Zalasiewicz, this issue, for molluscbased indications of Southern North Sea temperature). Indeed, a pattern of warming at mid and high latitudes with cooling or unchanged SSTs in low latitudes is shown in global reconstructions of the Pliocene based on faunal analysis techniques (e.g. Dowsett et al., 1999). Analysis of additional palaeoclimate data indicates warming at lower latitudes too (e.g. Haywood et al., 2005; Dekens et al., 2007; Dowsett and Robinson 2009).

\subsection{Southern Ocean and sea ice}

The Southern Ocean was typically warmer than present during the Early Pliocene (Hodell \& Warnke 1991) and the West Antarctic Ice Sheet records a $40 \mathrm{kyr}$ cyclic variation in ice sheet 
advance with periodic collapses when marine conditions returned to the Ross embayment during warm intervals (Naish et al., 2009). Dowsett (2007) reviewed the evidence for the extent of Southern Ocean sea ice and PRISM used winter reconstructions with sea ice between 4 and $6^{\circ}$ further south during the warm Piacenzian, and minimal sea ice during the summer, an inference supported by ANDRILL (Naish et al., 2009). Berkman et al. (2004) argued that the presence of Chlamys bivalves (now retreated to South America) in Antarctic Neogene fossil assemblages, suggested similar conditions to modern Patagonian seawaters, and in particular, much reduced sea ice cover. Jonkers (1998) also suggested a sea ice-free environment for the Early Pliocene Cockburn Island Formation (northern Weddell Sea), based on the presence of barnacles and the absence of ice-rafted debris. Opal depositional rates, which are linked to biological productivity, are conspicuously enhanced in the Early Pliocene, between 5.2 and 3.1 Ma, signifying much-reduced sea ice cover (Hillenbrand and Fütterer, 2002; Pudsey, 2002). Although microfossil assemblages found in the ODP Leg 178 drift sediments show no evidence of significantly warmer surface water temperatures than today (Hillenbrand and Fütterer, 2002), Hepp et al. (2006) have suggested open ocean conditions in the warm Early Pliocene, even during glacials. In addition, diatom evidence from ODP site 1165 (in the Southern Ocean at $64.384^{\circ} \mathrm{S}$ ) reported by Whitehead and Bohaty (2003) gives MATs at $4^{\circ} \mathrm{C}$. Bivalves and bryozoans have also proved useful for tracking seasonality in the Early Pliocene Weddell Sea (e.g. Clark et al., 2010). Data from these organisms suggest greater seasonality, warmer sea temperatures and much reduced sea ice throughout the year (Williams et al., 2010). Although at present these fossils provide only snapshots of Early Pliocene climate, extensive Neogene bivalve material from the Antarctic Peninsula (e.g. Jonkers 1998) and the East Antarctic (e.g. Quilty 2000 , p. 193) offers great potential for evaluating a longer term Pliocene record of Southern Ocean climate.

\subsection{Arctic and Subarctic}


Pliocene palaeoclimate records from the Arctic and subarctic are relatively sparse, but mid Piacenzian proxies from the Beaufort Sea suggest SST in this region might have been between $\sim 2-4^{\circ} \mathrm{C}$ warmer than at present (Dowsett et al., 1996), whilst proxies from the Fram Strait region suggest surface waters were $\sim 13-18^{\circ} \mathrm{C}$ warmer (Robinson 2009). This extreme warmth (compared to present) is consistent with modelling experiments that show a deepened Greenland-Scotland Ridge might have allowed warmer Atlantic surface water to extend much further into the Arctic (Robinson et al., this issue). Although these very high Pliocene SSTs have been interpreted as evidence for a seasonally ice-free Arctic (Robinson 2009), sediment-geochemistry sea ice proxies from the Lomonosov Ridge indicate perennial sea ice existed at least over the central Arctic Ocean from the Middle Miocene to Recent (Backman, et al., 2008, Krylov et al., 2008; Darby 2008). Alkenone-based proxies indicate subarctic Northeast Pacific summer SSTs were $\sim 2-4^{\circ} \mathrm{C}$ warmer than at present, whilst winter SSTs were $\sim 1-2^{\circ} \mathrm{C}$ cooler at Sites 886 and 183 (Haug et al., 2005; Dowsett et al., 2009). This discrepancy could be explained by typically marine surface water salinities, compared to the modern North Pacific where a significant halocline exists (Haug et al., 1999). It has been proposed that the development of this halocline after $\sim 3$ Ma stratified the water column, allowing warmer waters to persist later in the year and maximise autumn precipitation in North America initiating Northern Hemisphere Glaciation (Haug et al., 2005). Proxies for sea ice extent in the Pacific sector of the subarctic have yet to be fully resolved, but preliminary micropalaeontology results from recent Bering Sea cores indicates seasonal sea ice was not persistently present over Bowers Ridge in the Pliocene, but expanded to this region at $\sim 3 \mathrm{Ma}$ (Takahashi et al., 2010). Whilst the North Atlantic probably experienced less vigorous deep water production in the early Pliocene, possibly due to less dense Pacific waters moving into the Atlantic via the Central American Seaway (Poore et al., 2006), micropalaeontology proxies indicate the Bering Sea may have been better ventilated in the early Pliocene until the onset of Northern Hemisphere Glaciation (NHG) at approximately 3 Ma (Takahashi et al., 2010). 


\section{Pliocene Climate Modelling}

A significant number of Pliocene climate and environmental modelling studies are now available within the published literature. The majority of these studies have incorporated, either entirely or to a degree, one or more of the iterations of the US Geological Survey's boundary condition data set (PRISM - Pliocene Research Interpretations and Synoptic Mapping - P0 through to P3D), which are designed to facilitate numerical modelling studies of Pliocene climate (Dowsett et al., 1996; Dowsett et al., 1999; Dowsett et al., 2010). Much of the emphasis of the work published thus far has been on large-scale features of Pliocene climate. This has included analyses of the annual global mean surface temperature anomaly, as well as Pliocene equator to pole temperature gradients (e.g. Chandler et al., 1994; Sloan et al., 1996; Haywood et al., 2000a; Haywood and Valdes, 2004; Brierley et al., 2009), intensity of the hydrological cycle, patterns of atmospheric circulation (e.g. Haywood et al., 2000b; Jiang et al., 2005) and patterns of oceanic circulation (Haywood and Valdes, 2004).

Global MATs were $\sim 2$ to $3^{\circ} \mathrm{C}$ greater during warm intervals of the Pliocene compared to the pre-industrial era. The increase in surface temperature was amplified at the high-latitudes (largely through the ice-albedo feedback mechanism and a reduction in winter sea-ice cover allowing greater heat exchange between the cold atmosphere and relatively warm Arctic and Southern Oceans) with only minor warming (or no warming at all) predicted in the tropics. The net effect is a significant reduction in the equator to pole temperature gradient. This reduction in gradient is important since it is a driver of atmospheric circulation and therefore models predict a weakening in the global circulation strength for the Pliocene (Haywood et al., 2000a). Whilst this relationship holds true as a global mean, regional wind strengths can still be predicted to be enhanced compared to model predictions for the pre-industrial era. This apparent paradox is displayed when examining model predictions for wintertime midlatitude westerly wind strength in the Northern Hemisphere, which some models predict 
increase in the Pliocene scenario. This is due to a complex interaction of changes in North Atlantic SSTs and a reduction in the size of Greenland ice sheet which had the effect of increasing the regional atmospheric pressure gradient (through enhancing the Azores High and Icelandic Low) and invigorating the westerly winds (Haywood et al., 2000b). It is also now clear that the specified altitude of the western cordillera of North America has a significant effect on downstream circulation and cannot be ignored in this context (Hill et al., this issue).

The coupled ocean-atmosphere modelling study of Haywood and Valdes (2004) and Lunt et al. (2008) demonstrated that once the Central American Seaway closed a largely modern pattern of ocean circulation was established. However, significant differences in ocean surface current strength were predicted between the Pliocene and pre-industrial experiments. Of first order importance were the model's representation of the western (poleward flowing) and eastern (equatorward flowing) boundary currents. The strength of both Gulf Stream and Kuroshio Currents may have increased compared to present-day. The difference in meridional overturning streamfunction between the Pliocene and pre-industrial coupled experiment indicate that for the Pliocene coupled experiment the flow of Antarctic Bottom Water (AABW) may have been reduced by a maximum of $5 \mathrm{~Sv}$. The rate of downwelling in the Northern Hemisphere also appears to be reduced by up to $3 \mathrm{~Sv}$. For the Atlantic sector, the results indicate that, in the Pliocene case, AABW flow is either the same as, or locally slightly stronger than (1 to $6 \mathrm{~Sv}$ ) present. However the strength and depth of the North Atlantic Thermohaline circulation is reduced. For the Pacific Ocean, the only significant change predicted is a reduction in AABW flow by $4 \mathrm{~Sv}$. These results implied both a shallowing and slight reduction in the strength of the thermohaline circulation, and a reduction in AABW flow mainly in the Pacific Ocean in the Pliocene case (Haywood and Valdes, 2004). 
In terms of understanding the causes of Pliocene warmth the above style of analyses are invaluable but models are also capable of isolating the contribution to global MAT change derived from each Pliocene boundary condition. Initial results indicate that changes in the distribution of vegetation, reduced land ice, altered orography (although now highly questionable given the latest reconstructions of Late Pliocene topography that show little change from modern) and elevated concentrations of $\mathrm{CO}_{2}$ may have provided the largest contribution to global MAT change (Lunt et al., 2010). With an ability to isolate the contribution to temperature chang derived from different boundary conditions, and an increasing interest in the response of the total Earth System to $\mathrm{CO}_{2}$ concentrations in the longer term (including slower response time feedbacks from vegetation and land ice), the Pliocene is now making a major contribution to the assessment of Earth System Sensitivity (the response of global MAT to an increase in $\mathrm{CO}_{2}$ in the longer term including fast and slow feedbacks from vegetation and ice sheets). An initial estimate from Lunt et al. (2010) indicates that ESS may be 30 to $50 \%$ greater than Climate Sensitivity (Charney Sensitivity). If this estimate is upheld by further studies that fully explore uncertainty in ESS estimates for the Pliocene it will have major implications for climate policy and require a re-examination of $\mathrm{CO}_{2}$ stabilisation scenarios.

A central part of any of the type of analyses using climate models described above is the assessment of model skill. Compared to the achievements of the Quaternary data and modelling communities, data/model comparisons for warm intervals in the Pliocene are still in their infancy (however, see Dowsett et al., this issue which makes an important contribution by evaluating model predictions of SSTs) and must represent an area of concentration in the future. For this to succeed the Pliocene data community must follow their Quaternary counterparts and develop and publish full estimates of uncertainty on palaeoenvironmental data. Likewise, the modelling community will need to do far more than it has thus far to quantify uncertainty in model predictions for the Pliocene. This uncertainty comes from three primary sources: 1) partially constrained boundary conditions (e.g. see 
Robinson et al., this issue); 2) structural uncertainty (differences between models); and finally 3) parameter uncertainty (physics uncertainty) within single models (see Pope et al., this issue). Progress is being made on all these fronts (e.g. Haywood et al., 2010; Haywood et al., 2011) and should enable more sophisticated comparisons between data and models to occur within the near future.

Finally, it should be noted that all Pliocene modelling studies published thus far have utilised climate models that can no longer be considered state-of-the-art. The UK effort has thus far been focussed on the Hadley Centre Coupled Climate Model version 3 (HadCM3) which is an impressive model in terms of its ability to reproduce modern climate, but has been superseded by later versions of the Met Office model. The current production version of the Met Office model has a totally new dynamical core, improved resolution, physical parameterisations and range of earth system components. To retain the utility of the Pliocene to ground truth models used for future climate change it is important that the models used to predict future climate change are also used for warm intervals of the Pliocene.

\section{Conclusions}

Although not a true geological analogue, the Pliocene interglacials are certainly one of the best geological periods to study processes of the Earth system during warm, high $\mathrm{CO}_{2}$ climate states. No other warm period in the geological past yields such a unique combination of near-modern atmospheric $\mathrm{CO}_{2}$-concentrations, palaeogeography and palaeobiology. This makes the Pliocene an ideal "palaeo-laboratory" to understand our modern Earth System and to test climate models we rely on to produce accurate predictions of future climate change. 
A comparatively large set of proxy data has been made available for the Pliocene, which is one of the most intensively studied periods of the pre-Quaternary. A robust reconstruction of Piacenzian environments has been significantly supported by the collaborative data analysis and climate modelling efforts of the PRISM project (Dowsett et al., 1994; 2010). In the future, Pliocene studies by both data and modelling communities should:

- focus on data sparse regions which play a key role in our climate system, such as the Amazon and Antarctica (see Fig. 2)

- initialise models with updated boundary conditions and assess model outcomes and performance using climate model intercomparison and data-model comparison techniques. Both are the focus of the recently established PlioMIP program (Haywood et al. 2010).

- define new boundary conditions currently not included in the existing PRISM data set.

- focus on records which enable the reconstruction of orbital-scale variability during the mid Piacenzian warm period ( 3.3 to $3.0 \mathrm{Ma})$. Current data sets and boundary conditions used in model simulations generally use environmental reconstructions which are "averaged" over several glacial and interglacial cycles (e.g. Salzmann et al. 2008).

- explore new proxies to assess Pliocene seasonality, such as high resolution stable isotope records from bivalves, bryozoans and corals (e.g. Johnson et al. 2009, Valentine et al. this volume, Knowles et al., 2009, Watanabe et al., 2011).

\section{Acknowledgments}

We would like to thank all participants in our Pliocene session the EGU, Vienna 2010. US and $\mathrm{AH}$ acknowledge funding received from the Natural Environmental Research Council (NERC Grant NE/I016287/1).

\section{References}


Backman, J., Jakobsson, M., Frank, M., Sangiorgi, F., Brinkhuis, H., Stickley, C., O'Regan, M., Løvlie, R., Pälike, H., Spofforth, D., Gattacecca, J., Moran, K., King, J.Heil, C., 2008. Age model and core-seismic integration for the Cenozoic Arctic Coring Expedition sediments from the Lomonosov Ridge. Paleoceanography 23 (1), PA1S03.

Ballantyne, A.P., Greenwood, D.R., Sinninghe Damste, J.S., Csank, A.Z., Eberle, J.J., Rybczynski, N., 2010. Significantly warmer Arctic surface temperatures during the Pliocene indicated by multiple independent proxies. Geology 38 (7), 603-606

Barron, J.A., 1996. Diatom constraints on the position of the Antarctic Polar Front in the middle part of the Pliocene. Marine Micropaleontology 27 (1-4),195-213.

Bennike, O., Boecher, J., 1990. Forest-Tundra neighbouring the North Pole: Plant remains from the Plio-Pleistocene Kap Kobenhavn Formation, North Greenland. Arctic 43 (4), $331-338$.

Berkman, P.A., Cattaneo-Vietti, R., Chiantore, M., Howard-Williams, C., 2004. Polar emergence and the influence of increased sea-ice extent on the Cenozoic biogeography of pectinid molluscs in Antarctic coastal areas. Deep Sea Research Part 2, 51, 18391855.

Brierley, C.M., Fedorov, A.V., Liu, Z., Herbert, T.D., Lawrence, K.T., LaRiviere, J.P., 2009. Greatly Expanded Tropical Warm Pool and Weakened Hadley Circulation in the Early Pliocene. Science 323 (5922), 1714-1718.

Cane, M.A., Molnar, P., 2001. Closing of the Indonesian seaway as a precursor to east African aridification around 3-4 million years ago. Nature 411, 157-162.

Chandler, M., Rind, D., Thompson, R., 1994. Joint investigations of the middle Pliocene climate II: GISS GCM Northern Hemisphere results. Global and Planetary Change 9 (34), 197-219.

Ciesielski, P.F.; Weaver, F.M.; 1974. Early Pliocene temperature changes in the Antarctic seas. Geology, 2, 511-515. 
Clark, N., Williams, Okamura, B., M., Smellie, J., Nelson, A., Knowles, T., Taylor, P., Leng, M., Zalasiewicz, J.A., Haywood, A., 2010. Early Pliocene Weddell Sea seasonality determined from bryozoans. Stratigraphy, 7, 199-206.

Darby, D.A., 2008. Arctic perennial ice cover over the last 14 million years. Paleoceanography 23, PA1S07.

Dekens, P.S., Ravelo, A.C., McCarthy, M.D., 2007. Warm upwelling regions in the Pliocene warm period. Paleoceanography 22, PA3211. (doi:10.1029/2006PA001394).

De Schepper, S., Fischer, E., Groeneveld, J., Head, M.J., Matthiessen, J., 2011.

Deciphering the palaeoecology of Late Pliocene and Early Pleistocene dinoflagellate cysts. Palaeogeography, Palaeoclimatology, Palaeoecology, (this issue).

DeVernal, A., Mudie, P.J., 1989. Pliocene and Pleistocene Palynostratigraphy at ODP sites 646 and 647, Eastern and Southern Labrador Sea, in: S.P. Srivastava, M. ArthurM. Clement (Editors), Proceedings of the Ocean Drilling Program, Scientific Results, pp. $401-422$

Dodson, J.R., Macphail, M.K., 2004. Palynological evidence for aridity events and vegetation change during the Middle Pliocene, a warm period in Southwestern Australia. Global and Planetary Change 41 (3-4), 285-307.

Dolan, A.M., Haywood, A.M.,1, Hill, D.J., Dowsett, H.J., Hunter, S.J., Lunt D.J., Pickering, S. J., 2011. Sensitivity of Pliocene Ice Sheets to Orbital Forcing. Palaeogeography, Palaeoclimatology, Palaeoecology (this issue).

Dowsett, H.J., Haywood, A.M., Valdes, P.J., Robinson, M.M., Lunt, D.J., Hill, D.J., Stoll, D.K.Foley, K.M., 2011. Sea surface temperatures of the mid-Piacenzian Warm Period: A comparison of PRISM3 and HadCM3. Palaeogeography, Palaeoclimatology, Palaeoecology (this issue).

Dowsett, H.J., Robinson, M., Haywood, A., Salzmann, U., Hill, D., Sohl, L., Chandler, M., Williams, M., Foley, K., Stoll, D., 2010. The PRISM3D Paleoenvironmental Reconstruction. Stratigraphy 7, 123-139. 
Dowsett, H. J., Robinson, M. M., Foley, K. M., 2009 Pliocene three-dimensional global ocean temperature reconstruction. Climate of the Past 5, 769-783.

Dowsett, H.J., Robinson, M.M., 2009. Mid-Pliocene equatorial Pacific sea surface temperature reconstruction: a multi-proxy perspective. Philosophical Transactions of the Royal Society A: Mathematical, Physical and Engineering Sciences 367, 109-125.

Dowsett, H.J., 2007. The PRISM palaeoclimate reconstruction and Pliocene sea-surface temperature. In: Williams, M., Haywood, A.M., Gregory, F.J., Schmidt, D.N. (eds.) DeepTime Perspectives on Climate Change: Marrying the Signal from Computer Models and Biological Proxies. The Micropalaeontological Society, Special Publications, The Geological Society, London, pp. 459-480.

Dowsett, H. J., Barron, J. A., Poore, R. Z., Thompson, R. S., Cronin, T. M., Ishman, S.E., Willard, D. A., 1999. Middle Pliocene paleoenvironmental reconstruction: PRISM2. US Geological Survey Open File Report 99-535.

Dowsett, H.J., Barron, J., Poore, R., 1996. Middle Pliocene sea surface temperatures: a global reconstruction, Marine Micropaleontology, 27, 13-25.

Dowsett, H.J., Cronin, T., Poore, R.Z., Thompson, R.S., Whatley, R.C., Wood, A.M., 1992. Micropaleontological evidence for increased meridional heat transport in the North Atlantic Ocean during the Pliocene. Science 258, 1133-1135.

Fauquette, S., Suc, J.P., Guiot, J., Diniz, F., Feddi, N., Zheng, Z., Bessais, E., Drivaliari, A., 1999. Climate and biomes in the West Mediterranean area during the Pliocene. Palaeogeography Palaeoclimatology Palaeoecology 152 (1-2), 15-36.

Federov, A.V., Brierley, C.M., Emanueal, K., 2010. Tropical cyclones and permanent El Niño in the early Pliocene epoch. Nature 463, 1066-1071.

Fleming, R.F., Barron, J.A., 1996. Evidence of Pliocene Nothofagus in Antarctica from Pliocene marine sedimentary deposits (DSDP Site 274). Marine Micropaleontology 27 (14), 227-236. 
Fox, D.L., Koch, P.L., 2004. Carbon and oxygen isotopic variability in Neogene paleosol carbonates: constraints on the evolution of the C4-grasslands of the Great Plains, USA. Palaeogeography, Palaeoclimatology, Palaeoecology 207 (3-4), 305-329.

Francis, J.E., Hill, R.S., 1996. Fossil plants from the Pliocene Sirius Group, Transantarctic Mountains; evidence for climate from growth rings and fossil leaves. PALAIOS 11 (4), 389-396.

Gibbard, P.L., Head, M.J., Walker, M.J.C., Subcommision on Quaternary Stratigraphy, 2010. Formal ratification of the Quaternary System/ Period and the Pleistocene Series/Epoch with a base at 2.58 Ma. Journal of Quaternary Science 25 (2), 96-102.

Hansen, B.C.S., Grimm, E.C., Watts, W.A., 2001. Palynology of the Peace Creek site, Polk County, Florida. Geological Society of America Bulletin 113 (6), 682-692.

Haug, G. G., Sigman, D. M., Tiedemann, R., Pedersen, T. F., Sarnthein, M., 1999. Onset of permanent stratification in the subarctic Pacific Ocean. Nature 40, 779-782.

Haug, G.H., Ganopolski, A., Sigman, D.M., Rosell-Mele, A., Swann, G.E.A., Tiedemann, R., Jaccard, S.L., Bollmann, J., Maslin, M.A., Leng, M.J.Eglinton, G., 2005. North Pacific seasonality and the glaciation of North America 2.7 million years ago. Nature 433 (7028), 821-825.

Haywood, A.M., Ridgwell, A., Lunt, D.J., Hill, D.J., Pound, M.J., Dowsett, H.J., Dolan, A.M., Francis, J.E., Williams, M., 2011. Are there pre-Quaternary geological analogues for a future greenhouse warming? Philosophical Transactions of the Royal Society A: Mathematical, Physical and Engineering Sciences 369 (1938), 933-956.

Haywood, A.M., Dowsett, H.J., Otto-Bliesner, B., Chandler, M.A., Dolan, A.M., Hill, D.J., Lunt, D.J., Robinson, M.M., Rosenbloom, N., Salzmann, U., Sohl, L.E., 2010. Pliocene Model Intercomparison Project (PlioMIP): experimental design and boundary conditions (Experiment 1). Geoscientific Model Development 3 (1), 227-242.

Haywood, A.M., Dekens, P., Ravelo, A.C. \& Williams, M., 2005. Warmer tropics during the Mid-Pliocene? Evidence from alkenone paleothermometry and a fully coupled oceanatmosphere GCM. Geochem. Geophys. Geosyst. 6, 1-20. (doi:10.1029/2004GC000799) 
Haywood, A.M., Valdes, P.J., 2004. Modelling Pliocene warmth: contribution of atmosphere, oceans and cryosphere. Earth and Planetary Science Letters 218 (3-4), 363-377.

Haywood, A.M., Valdes, P.J., Sellwood, B.W., 2000a. Global scale palaeoclimate reconstruction of the middle Pliocene climate using the UKMO GCM: initial results. Global and Planetary Change 25 (3-4), 239-256.

Haywood, A.M., Sellwood, B.W., Valdes, P.J., 2000b. Regional warming: Pliocene (3 Ma) paleoclimate of Europe and the Mediterranea. Geology 28, 1063-1066.

Hepp, D.A., Mörz, T., Grützner, J., 2006. Pliocene glacial cyclicity in a deep-sea sediment drift (Antarctic Peninsula Pacific Margin). Palaeogeography, Palaeoclimatology, Palaeoecology, $231,181-198$.

Hill, D.J., Csank, A.Z., Dolan, A.M., Lunt, D.J., 2011. Pliocene climate variability: Northern Annular Mode in models and tree-ring data. Palaeogeography, Palaeoclimatology, Palaeoecology (this issue).

Hillenbrand, C-D., Fütterer, D.K., 2002. Neogene to Quaternary deposition of opal on the continental rise west of the Antarctic Peninsula, ODP Leg 178, Sites 1095, 1096, and 1101. In: Barker, P.F., Camerlenghi, A., Acton, G.D., Ramsay, A.T.S. (eds) Proceedings of the Ocean Drilling Programme, Scientific Results, 178. Texas A and M University, College Station, Texas, 1-40 (CD-ROM).

Hodell, D.A., Warnke, D.A. 1991. Climatic evolution of the Southern Ocean during the Pliocene Epoch from 4.8 to 2.6 million years ago. Quaternary Science Reviews, 10, 205214.

IPCC, 2007. Climate Change 2007: The Physical Science Basis. Contribution of Working Group I to the Fourth Assessment. Report of the Intergovernmental Panel on Climate Change. In: S. Solomon, D. Qin, M., Manning, Z. Chen, M. Marquis, K.B. Averyt, M. Tignor, Miller, H.L (Editors), Report of the Intergovernmental Panel on Climate Change. Cambridge University Press, Cambridge and New York. Johnson, A., Hickson, J., Bird, A., Schoene, B., Balson, P., Heaton, T., Williams, M. 2009. Comparative sclerochronology of modern and mid-Pliocene (c. 3.5 Ma) Aequipecten 
opercularis (Mollusca, Bivalvia): an insight into past and future climate change in the north-east Atlantic region. Palaeogeography, Palaeoclimatology, Palaeoecology, 284, 164-179.

Jonkers, H.A., 1998. The Cockburn Island Formation; Late Pliocene interglacial sedimentation in the James Ross Basin, northern Antarctic Peninsula. Newsletters on Stratigraphy, 36, 63-76.

Karas, C., Nürnberg, D., Gupta, A.K., Tiedemann, R., Mohan, K., Bickert, T., 2009. MidPliocene climate change amplified by a switch in Indonesian subsurface throughflow. Nature Geoscience 2, 434-438.

Kershaw, A.P., Sluiter, I.R., 1982. Late Cenozoic Pollen Spectra from the Atherton Tableland, North-eastern Australia. Australian Journal of Botany 30, 279-295. Khélifi, N., Sarnthein, M., Andersen, N., Blanz, T., Frank, M., Garbe-Schonberg, D., Haley, B.A., Stumpf, R.Weinelt, M., 2009. A major and long-term Pliocene intensification of the Mediterranean outflow, 3.5-3.3 Ma ago. Geology 37 (9), 811-814.

Knowles, T., Taylor, P.D., Williams, M., Haywood, A.M., Okamura, B., 2009. Pliocene seasonality across the North Atlantic inferred from cheilostome bryozoans. Palaeogeography, Palaeoclimatology, Palaeoecology 277, 226-235.

Krebs, U., Park, W., Schneider, B., 2011. Pliocene aridification of Australia caused by tectonically induced weakening of the Indonesian throughflow. Palaeogeography, Palaeoclimatology, Palaeoecology (this issue).

Krylov, A.A., Andreeva, I.A., Vogt, C., Backman, J., Krupskaya, V.V., Grikurov, G.E., Moran, K.Shoji, H., 2008. A shift in heavy and clay mineral provenance indicates a middle Miocene onset of a perennial sea ice cover in the Arctic Ocean. Paleoceanography 23 (1), PA1S06.

Leroy, S., Dupont, L., 1994. Development of vegetation and continental aridity in northwestern Africa during the Late Pliocene: the pollen record of ODP site 658. Palaeogeography, Palaeoclimatology, Palaeoecology 109 (2-4), 295-316. 
Li, Q., Li, B., Zhong, G., McGowan, B., Zhou, Z., Wang, J., Wang, P., 2006. Late Miocene development of the western Pacific warm pool: planktonic foraminifer and oxygen isotope evidence. Palaeogeography, Palaeoclimatology, Palaeoecology 237, 465-482.

Lisiecki, L.E., Raymo, M.E., 2005. A Pliocene-Pleistocene stack of 57 globally distributed benthic $\mathrm{d}^{18} \mathrm{O}$ records. Paleoceanography 20 (1), PA1003.

Long, P.E., Zalasiewicz, J. (2011). The molluscan fauna of the Coralline Crag (Pliocene, Zanclean) at Raydon Hall, Suffolk, UK: palaeoecological significance reassessed. Palaeogeography, Palaeoclimatology, Palaeoecology, (this issue).

Lunt, D.J., Haywood, A.M., Schmidt, G.A., Salzmann, U., Valdes, P.J., Dowsett, H.J., 2010. Earth system sensitivity inferred from Pliocene modelling and data. Nature Geoscience 3 (1), 60-64.

Lunt, D.J., Valdes, P. J., Haywood, A. M., Rutt, I. C., 2008. Closure of the Panama Seaway during the Pliocene: implications for climate and Northern Hemisphere glaciation.Climate Dynamics 30, 1-18.

Mai, H.D., 1995. Tertiaere Vegetationsgeschichte Europas. Gustav Fischer Verlag, Jena Stutgart New York.

Naish, T., et al. (2009). Obliquity-paced Pliocene West Antarctic ice sheet oscillations. Nature, 458, 321-329.

Pagani, M., Liu, Z., LaRiviere, J., Ravelo, A.C., 2010. High Earth-system climate sensitivity determined from Pliocene carbon dioxide concentrations. Nature Geoscience 3 (1), $27-$ 30.

Pope, J.O., Collins, M., Haywood, A.M., Dowsett, H.J., Hunter, S.J., Lunt, D.J., Pickering, S.J., Pound, M.J., 2011. Quantifying Uncertainty in Model Predictions for the Pliocene (Plio-QUMP): Initial Results. Palaeogeography, Palaeoclimatology, Palaeoecology (this issue).

Poore, H.R., Samworth, R., White, N.J., Jones, S.M., McCave, I.N., 2006. Neogene overflow of Northern Component Water at the Greenland-Scotland Ridge. Geochemistry Geophysics Geosystems 7, Q06010. 
Pudsey, C.J., 2002. Neogene record of Antarctic Peninsula glaciation in continental rise sediments: ODP Leg 178, Site 1095. In: Barker, P.F., Camerlenghi, A., Acton, G.D., Ramsay, A.T.S. (eds) Proceedings of the Ocean Drilling Programme, Scientific Results, 178. Texas A and M University, College Station, Texas, 1-40 (CD-ROM).

Quilty, P., 2000. Foraminifera from Late Pliocene sediments of Heidemann Valley, Vestfold Hills, East Antarctic. Journal of Foraminiferal Research 40, 193-205.

Ragaini, L., Di Celma, C., Cantalamessa, G., 2008. Warm-water mollusc assemblages from northern Chile (Mejillones Peninsula): new evidence for permanent El Niño-like conditions during Pliocene warmth? Journal of the Geological Society, London, 165, 1075-1084.

Ravelo, A.C., 2006. Walker circulation and global warming. Lessons from the geological past. Oceanography 19, 114-122.

Ravelo, A.C., Dekens, P.S., McCarthy, M. 2006. Evidence for El Niño-like conditions during the Pliocene. GSA Today 16:4-11.

Reguero, M.A., Candela, A.M., Alonso, R.N., 2007. Biochronology and biostratigraphy of the Uquía Formation (Pliocene-early Pleistocene, NW Argentina) and its significance in the Great American Biotic Interchange. Journal of South American Earth Sciences 23 (1), 116.

Robinson, M.M., Valdes, P.J., Haywood, A.M., Dowsett, H.J., Hill, D.J., Jones, S.M., 2011. Bathymetric controls on Pliocene North Atlantic and Arctic sea surface temperature and deepwater production. Palaeogeography, Palaeoclimatology, Palaeoecology (this issue). Robinson, M.M., 2009. New quantitative evidence of extreme warmth in the Pliocene Arctic. Stratigraphy 6, 265-275.

Salzmann U., Nelson A.E., Riding J.B., Smellie, J. L. 2011. How likely is a green Antarctic Peninsula during warm Pliocene interglacials? A critical reassessment based on new palynofloras from James Ross Island. Palaeogeography, Palaeoclimatology, Palaeoecology (this issue). 
Salzmann, U., Haywood, A.M., Lunt, D.J., 2009. The past is a guide to the future?

Comparing Middle Pliocene vegetation with predicted biome distributions for the twentyfirst century. Philosophical Transactions of the Royal Society A: Mathematical, Physical and Engineering Sciences 367 (1886), 189-204.

Salzmann, U., Haywood, A.M., Lunt, D.J., Valdes, P.J., Hill, D.J., 2008. A new global biome reconstruction and data-model comparison for the Middle Pliocene. Global Ecology and Biogeography 17 (3), 432-447.

Schmidt, D.N., 2007. The closure history of the Central American seaway: evidence from isotopes and fossils to models and molecules. In Williams, M., Haywood, A.M., Gregory, F.J.; Schmidt, D.N. (eds). Deep-time perspectives on climate change: marrying the signal from computer models and biological proxies. The Micropalaeontological Society, Special Publications. The Geological Society, London, 477-442.

Seki, O., Foster, G.L., Schmidt, D.N., Mackensen, A., Kawamura, K.Pancost, R.D., 2010. Alkenone and boron-based Pliocene pCO2 records. Earth and Planetary Science Letters $292(1-2), 201-211$.

Sloan, L.C., Crowley, T.J., Pollard, D., 1996. Modeling of middle Pliocene climate with the NCAR GENESIS general circulation model. Marine Micropaleontology 27, (1/4): 51-61.

Suc, J.P., Bertini, A., Combourieu-Nebout, N., Diniz, F., Leroy, S., Russo-Ermolli, E., Zheng, Z., Bessais, E.Ferrier, J., 1995. Structure of West Mediterranean and climate since 5.3 Ma. Acta Zool. Cracov. 38, 3-16.

Takahashi, K., Ravelo, A.C., Alvarez Zarikian, C.A. and the Expedition 323 Scientists 2010 Proceedings of the Integrated Ocean Drilling Program 323, Tokyo (Integrated Ocean Drilling Program Management, Inc.) doi: 10.2204/iodp.proc.323.102.2010.

Thompson, R.S., 1991. Pliocene environments and climates in the western United States. Quaternary Science Reviews 10 (2-3), 115-13.

Utescher, T., Mosbrugger, V.Ashraf, A.R., 2000. Terrestrial Climate Evolution in Northwest Germany over the Last 25 Million Years. Palaios 15 (5), 430-449. 
Valentine, A., Johnson, A.L.A., Leng, M.J., Sloane, H.J., Balson, P., 2011. Isotopic evidence of cool winter conditions in the mid-Piacenzian (Pliocene) of the southern North Sea Basin. Palaeogeography, Palaeoclimatology, Palaeoecology, (this issue).

Watanabe, T., Suzuki, A., Minobe, S., Kawashima, T., Kameo, K., Minoshima, K., Aguilar, Y.M., Wani, R., Kawahata, H., Sowa, K., Nagai, T.Kase, T., 2011. Permanent El Niño during the Pliocene warm period not supported by coral evidence. Nature 471 (7337), 209-211.

Whitehead, J.M., Bohaty, S.M., 2003. Pliocene summer sea surface temperature reconstruction using silicoflagellates from Southern Ocean ODP Site 1165. Paleoceanography, 18, 1075, doi:1029/2002PA000829.

Whitehead, J.M., Wotherspoon, S., Bohaty, S.M., 2005. Minimal Antarctic sea ice during the Pliocene. Geology, 33, 137-140.

Willard, D.A., 1994. Palynological record from the North Atlantic region at 3 Ma: vegetational distribution during a period of global warmth. Review of Palaeobotany and Palynology 83 (4), 275-297.

Williams, M., Haywood, A.M., Harper, E.M., Johnson, A., Knowles, T., Leng, M.J., Lunt, D., Okamura, B., Taylor, P., Zalasiewicz, J.A., 2009. Pliocene climate and seasonality in North Atlantic shelf seas. Philosophical Transactions of the Royal Society, London, Series A, 367, 85-108, doi:10.1098/rsta.2008.0224.

Williams, M., Nelson, A.E., Smellie, J.L., Leng, M.J., Johnson, A.L.A., Jarram, D.R., Haywood, A.M., Peck, V.L., Zalasiewicz, J., Bennett, C., Schöne, B.R., 2010. Sea ice extent and seasonality for the Early Pliocene northern Weddell Sea determined from fossil Austrochlamys bivalves. Palaeogeography, Palaeoclimatology, Palaeoecology, 292, 306318. 

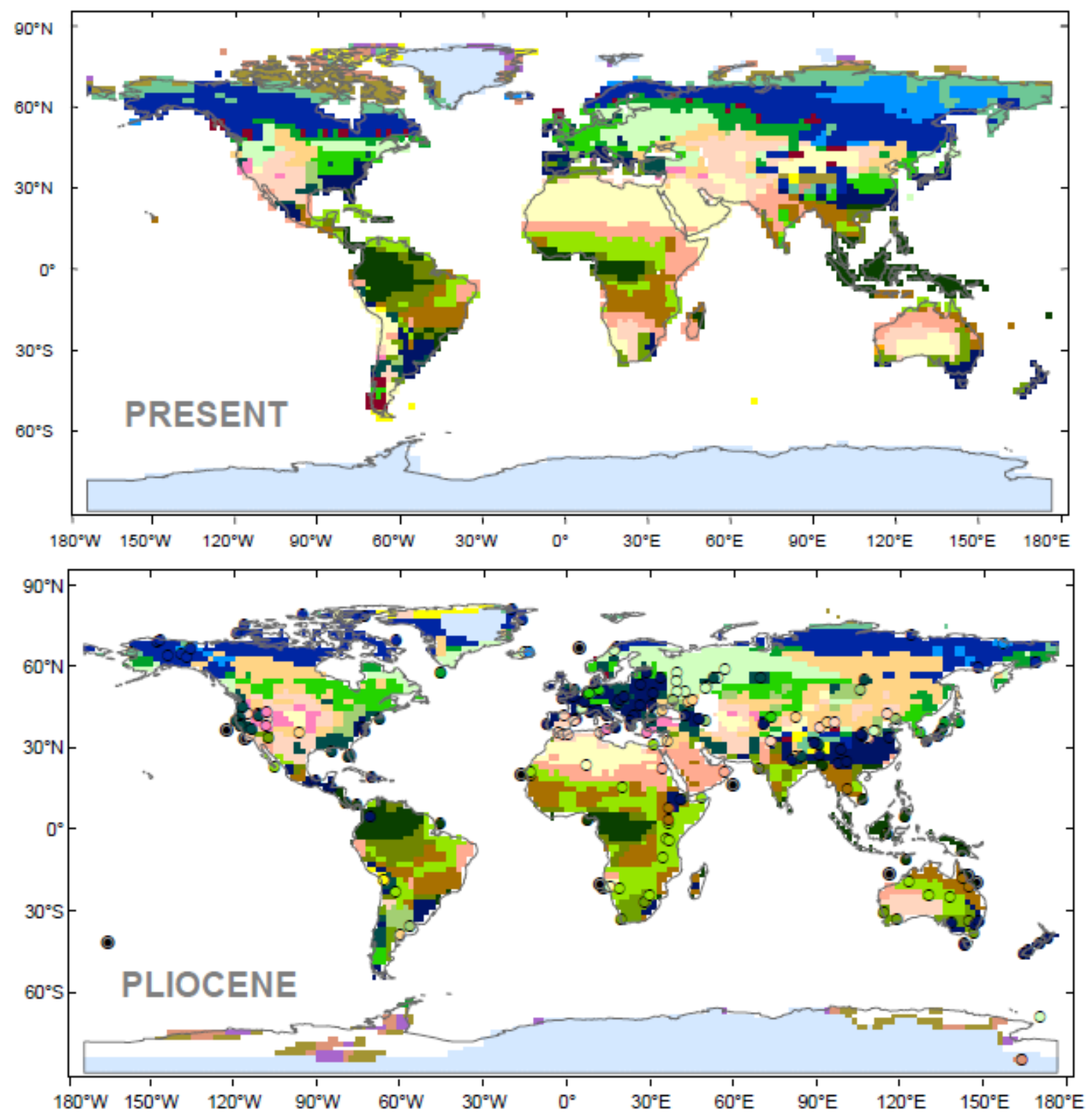

\begin{tabular}{|c|c|c|}
\hline tropical evergreen forest & temperate conifer forest & deciduous taiga/montane forest \\
\hline tropical semi-deciduous forest & cool mixed forest & tropical savanna \\
\hline tropical deciduous forest/woodland & cool conifer forest & tropical xerophytic shrubland \\
\hline warm-temperate mixed forest & cold mixed forest & temperate xerophytic shrubland \\
\hline temperate deciduous forest & evergreen taiga/montane forest & temperate sclerophyll woodland \\
\hline temperate broadleaved savanna & steppe tundra & desert \\
\hline open conifer woodland & shrub tundra & land ice \\
\hline boreal parkland & dwarf-shrub tundra & paleo-site \\
\hline tropical grassland & prostrate shrub tundra & marine core \\
\hline temperate grassland & cushion-forb, lichen, moss tundra & \\
\hline
\end{tabular}

Fig. 1: Global map of observed biomes (upper figure) and Late Pliocene data-model hybrid biome reconstruction (lower figure), based on 202 palaeobotanical sites and the output of a HadAM3/BIOME4 vegetation model (modified after Salzmann et al., 2008) 